\title{
Degradation of Profenofos in Soil inoculated with Bacillus cereus and Aneurinibacillus migulanus
}

\section{Anitha Palanimanickam ${ }^{1}$ and Umamaheswari Sepperumal ${ }^{2}$}

\author{
${ }^{1}$ Research Department of Zoology, Seethalakshmi Ramaswami college, Tiruchirappalli -620 002, \\ Tamil Nadu, India \\ ${ }^{2} P G$ and Research Department of Zoology, Periyar EV R College, Tiruchirappalli - 620 023, Tamil \\ $\mathrm{Nadu}$, India.
}

\begin{abstract}
The unplanned application of pesticide in paddy crop field to enhance paddy production could cause adverse impact on the environment. The present study was aimed to isolate the bacteria prevalent in profenofos applied soil to determine their profenofos degrading ability and its assay of the degraded metabolites. The dominant bacteria isolated from paddy crop field soil were Bacillus cereus and Aneurinibacillus migulanus. These bacteria were spiked with profenofos. After 36 hours of incubation in soil the extract were analysed by GCM S. Profenofos degradation was enhanced by Aneurinibacillus migulanus (99.45\% of profenfos degraded) compared to Bacillus cereus $(98.01 \%)$ and control (88.46\%). Thus Aneurinibacillus migulanus could be used as bioagents to degrade profenofos.
\end{abstract}

Keywords: Profenofos, Bacillus cereus, Aneurinibacillus migulanus, GC-M S, B iodegradation.

\section{Introduction}

Persistence of pesticide residues in crop field soil is of environmental concern. Though several research works are in progress to solve this issue, viable, cost effective and ecofriendly protocols is the need of the hour. The persistence of organisms in pesticide contaminated soil implies that these organisms would have developed certain mechanism to metabolize these residues. With this perspective, this study was undertaken to trace the bacteria persist in profenofos applied paddy crop field soil and to assess their potential to degrade profenofos.

*A uthor for Correspondence. E-mail: umadurai73@yahoo.com 


\section{Material and M ethods}

\section{Sample Collection:}

Profenofos applied paddy crop field soil were collected from Kelekalkandar kottai village, Tiruchirappalli district, Tamilnadu, India, in sterile autoclaved screw capped glass bottles, and kept at $4^{\circ} \mathrm{C}$ until processing. Further Research work was carried out in PG Research Department of Zoology, Periyar EV R College, Tiruchirappalli district, Tamil nadu, India.

\section{Isolation of pesticide resistant bacteria from paddy crop field soil:}

$1 \mathrm{~g}$ of profenofos applied paddy crop field soil was aseptically inoculated in $99 \mathrm{ml}$ of sterile minimal salt media (MSM) into cotton plugged flasks in triplicates. Conical flasks were kept under continuous shaking at room temperature for one week. M inimal salt media containing the following salts: $\mathrm{CaCl}_{2}-0.002 \mathrm{~g}, \mathrm{M} \mathrm{gCl}_{2}-0.02 \mathrm{~g}, \mathrm{~K}_{2} \mathrm{HPO}_{4}-0.1 \mathrm{~g}, \mathrm{KH}_{2} \mathrm{PO}_{4}-0.1 \mathrm{~g}, \mathrm{NH}_{4} \mathrm{NO}_{3}-$ $0.1 \mathrm{~g}$ and $\mathrm{FeCl} 3$ trace amount in distilled water (pH 7.2 - 7.4) up to $1 \mathrm{~L}$ were used for inoculation of soil sample. Total heterotrophic bacteria were isolated and identified following Bergey's manual of Determinative Biology [1]. The dominant bacteria Bacillus cereus and Aneurinibacillus migulanus were selected for pesticide degradation studies.

\section{Profenofos in soil inoculated with Bacillus cereus and Aneurinibacillus migulanus.}

Bacillus cereus was subcultured in autoclaved nutrient broth for 48 hours at $30^{\circ} \mathrm{C}$ in a rotatory shaker at $150 \mathrm{rpm}$. After 48 hours, $1 \mathrm{ml}\left(100 \mu \mathrm{l}: 45 \times 10^{15} \mathrm{cfu} / \mathrm{ml}\right)$ of Bacillus cereus broth culture was incubated into $50 \mathrm{~g}$ of sterile paddy crop field soil in $250 \mathrm{ml}$ of cotton plugged conical flask containing $5000 \mathrm{ppm}$ profenofos for 36 hours in triplicates. $20 \mathrm{ml}$ of autoclaved minimal salt medium was added to maintain $60 \%$ of humidity. Control (without Bacillus cereus) was maintained simultaneously. Similar procedure was followed for Aneurinibacillus migulanus (100 $\left.\mu \mathrm{l}: 67 \times 10^{15} \mathrm{cfu} / \mathrm{ml}\right)$.

\section{GC-MS analysis of degraded metabolites of Profenofos}

After 36 hours of incubation the samples were subjected to GC-MS analysis. The control and Profenofos treated soil were extracted for GCM S analysis based on the method of M alghani et al., (2009) [2] with minor modifications. The pesticides in the control and treatment were extracted using organic solvent extraction three times with acetone and hexane (1:1) mixture, then the extract was concentrated using rotary vacuum evaporator (Buchi R-210, Surkzer) and cleaned up in silica gel column. The pesticide extract were eluted with $n$-hexane collected in a glass vial and subjected to Gas chromatograph- M ass Spectrometer (GC-M S) analysis.

\section{Instrumental Analysis}

The qualitative and quantitative determination of Profenofos was performed by GC- MS (45 X GC 
44, B ruker) equipped with auto injector (8410). The separation analysis was performed in a 60 $\mathrm{mm} \times 0.25 \mathrm{~mm}$ I.D $\times 0.25 \mu \mathrm{m}$ film thickness BR $5 \mathrm{~ms}$ column (M ade in USA) and helium was used as a carrier gas at a flow rate of $1 \mathrm{ml} / \mathrm{min}$. The column temperature was programmed as 70 ${ }^{\circ} \mathrm{C}$ to $150^{\circ} \mathrm{C}$ at $10{ }^{\circ} \mathrm{C} / \mathrm{min}$, to $250{ }^{\circ} \mathrm{C}$ at $5{ }^{\circ} \mathrm{C} / \mathrm{min}$, to $280{ }^{\circ} \mathrm{C}$ at $2{ }^{\circ} \mathrm{C} / \mathrm{min}$, finally to $320{ }^{\circ} \mathrm{C}$ at $50 \mathrm{C} / \mathrm{min}$ and hold for 10 minutes. $1 \mu \mathrm{l}$ of the extract was injected into the injection port (at 280 $\left.{ }^{\circ} \mathrm{C}\right)$ using auto injector. The mass spectrometer was operated in scan mode and the ion source

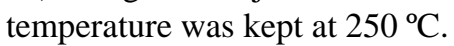

The electron ionization (EI) unit was operated at $70 \mathrm{eV}$ and at an emission current of $60 \mu \mathrm{A}$. Full scan data was obtained in a mass range of $\mathrm{m} / \mathrm{z}$ 50-650. Scanning interval and sample rate were 0.5 and 0.28 , respectively.

\section{Results}

Bacteria were isolated from paddy crop field soil exposed to Profenofos. The 16S rRNA gene sequencing was performed and identified as Bacillus cereus (Gene Bank Accession Number: K Y 293394) and Aneurinibacillus migulanus (Gene B ank A ccession N umber: KY 293393).

Residual quantification analysis of Profenofos by gas chromatography due to bacterial activity is presented in table 1. Relative to control (88.46\%), Bacillus cereus and Aneurinibacillus migulanus elicited $98.01 \%$ and $99.45 \%$, respectively. These results indicate that Bacillus cereus and Aneurinibacillus migulanus triggered the complete degradation of profenofos.

Table 1: GCM S depicting result showing the biodegradation of Profenofos by Bacillus cereus and Aneurinibacillus migulanus after 36 hours of exposure.

\begin{tabular}{|c|c|c|c|c|}
\hline Treatment & RT & A rea & $\begin{array}{c}\text { Pesticide } \\
\text { Residual } \\
\text { (ppm) }\end{array}$ & $\begin{array}{c}\text { \% of } \\
\text { degraded } \\
\text { pesticide }\end{array}$ \\
\hline $\begin{array}{c}\text { Control } \\
\text { Soil+5000 ppm profenofos }\end{array}$ & 14.218 & 447000000000 & 576.774 & 88.46 \\
\hline $\begin{array}{c}\text { Test soil+5000 ppm } \\
\text { profenofos } \\
+1 \mathrm{ml} \text { Bacillus cereus }\end{array}$ & 14.249 & 77060000000 & 99.432 & 98.01 \\
\hline $\begin{array}{c}\text { Test soil+5000 ppm } \\
\text { profenofos } \\
1 \mathrm{ml} \text { Aneurinibacillus } \\
\text { migulanus. }\end{array}$ & 14.256 & 21200000000 & 27.354 & 99.45 \\
\hline
\end{tabular}


In the control soil, apart from profenofos the various metabolites obtained were n-propyl benzene, 1-ethyl-2-methyl benzene, Isopropyl benzene, 1,2,3-trimethyl benzene, 0-Butyl 0, 0-diethyl phosphorothioate and 4-bromo-2-chloro phenol (Fig 1,1a, table 2). Profenofos residue was persistence in Bacillus cereus inoculated soil were 1-ethyl-2-methyl-benzene and 4-bromo-2chlorophenol (Fig 2, 2a).

Fig : 1 Gas Chromatogram of $5000 \mathrm{ppm}$ of Profenofos (control) at 36 hour in soil

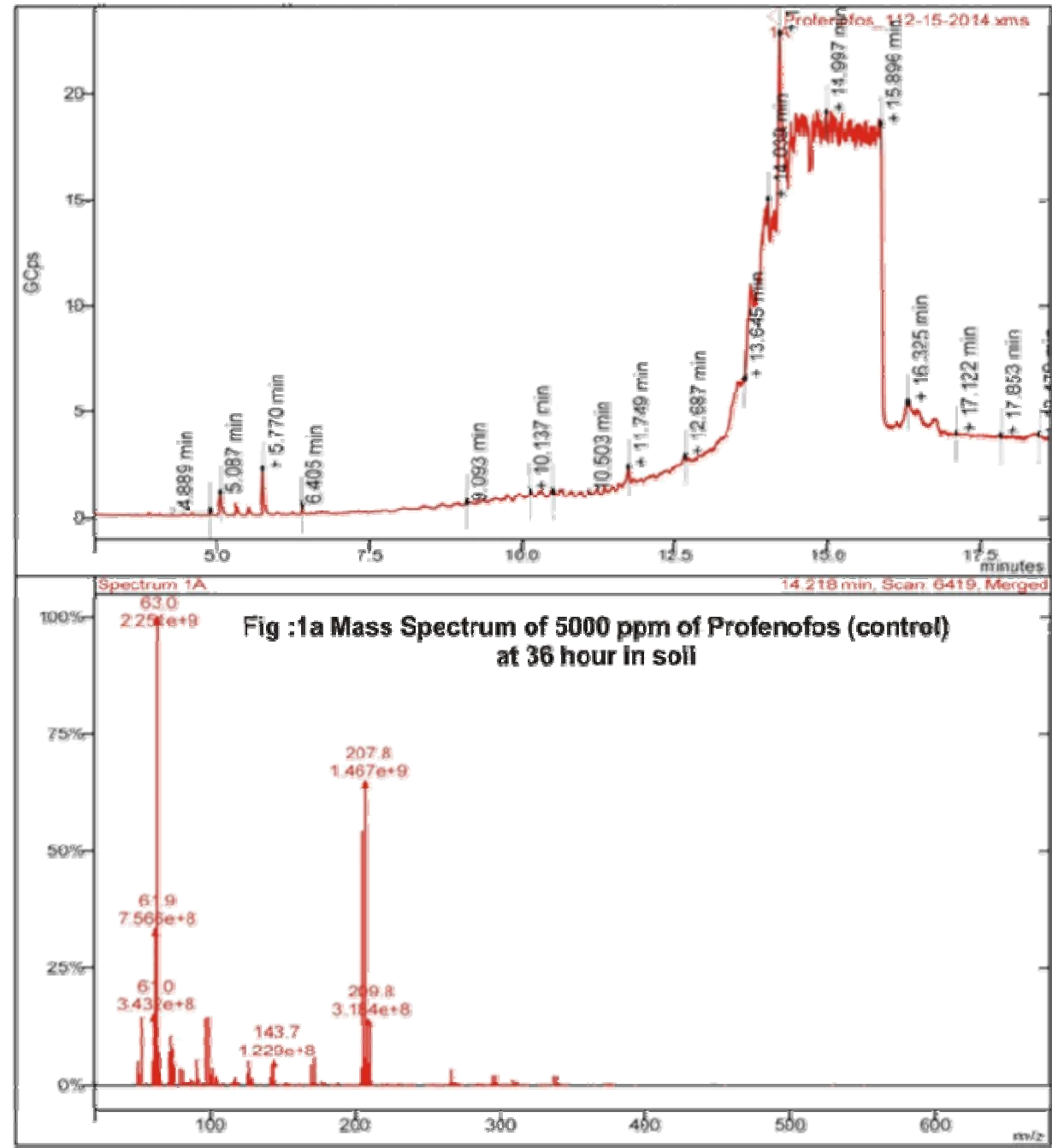


Fig: 2 Gas chromatogram of $5000 \mathrm{ppm}$ of Profenofos degraded by Bacifus cereus at $\mathbf{3 6}$ hour in soil

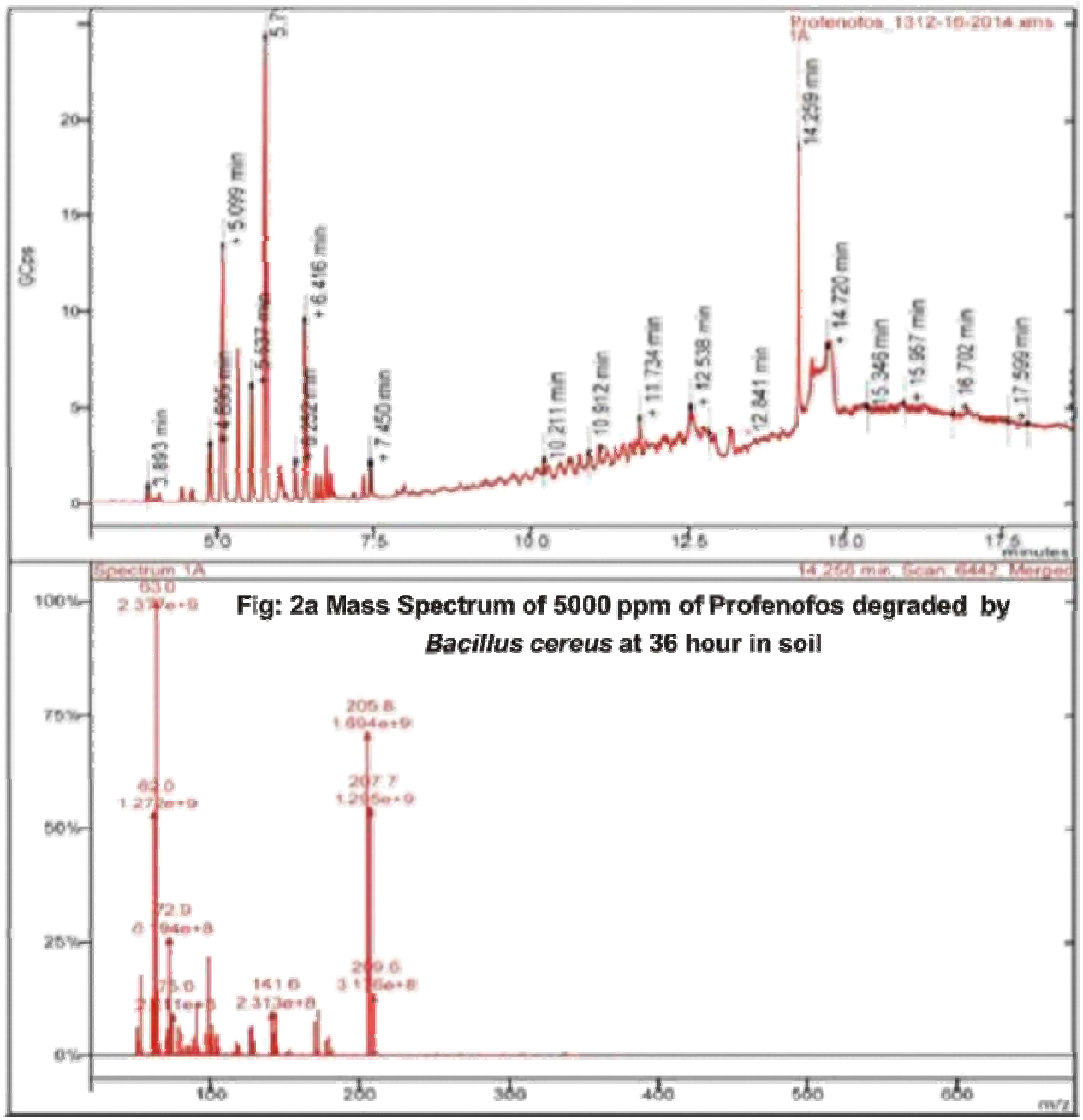

Inoculation of $5000 \mathrm{ppm}$ of profenofos with Aneurinibacillus migulanus degraded profenofos into Ethyl benzene, n-propyl benzene, 1-ethyl-3-methyl benzene, isopropyl benzene, 1,2,3 trimethyl benzene, 2-ethyl,1,3- dimethyl benzene, 0-B utyl 0,0 diethyl phosphorothioate and 4-bromo-2chloro phenol (Fig 3,3a, table 2). 
Fig: 3 Gas chromatogram of $5000 \mathrm{ppm}$ of Profenofos degraded by Aneurinibacillus migulanus at 36 hour in soil

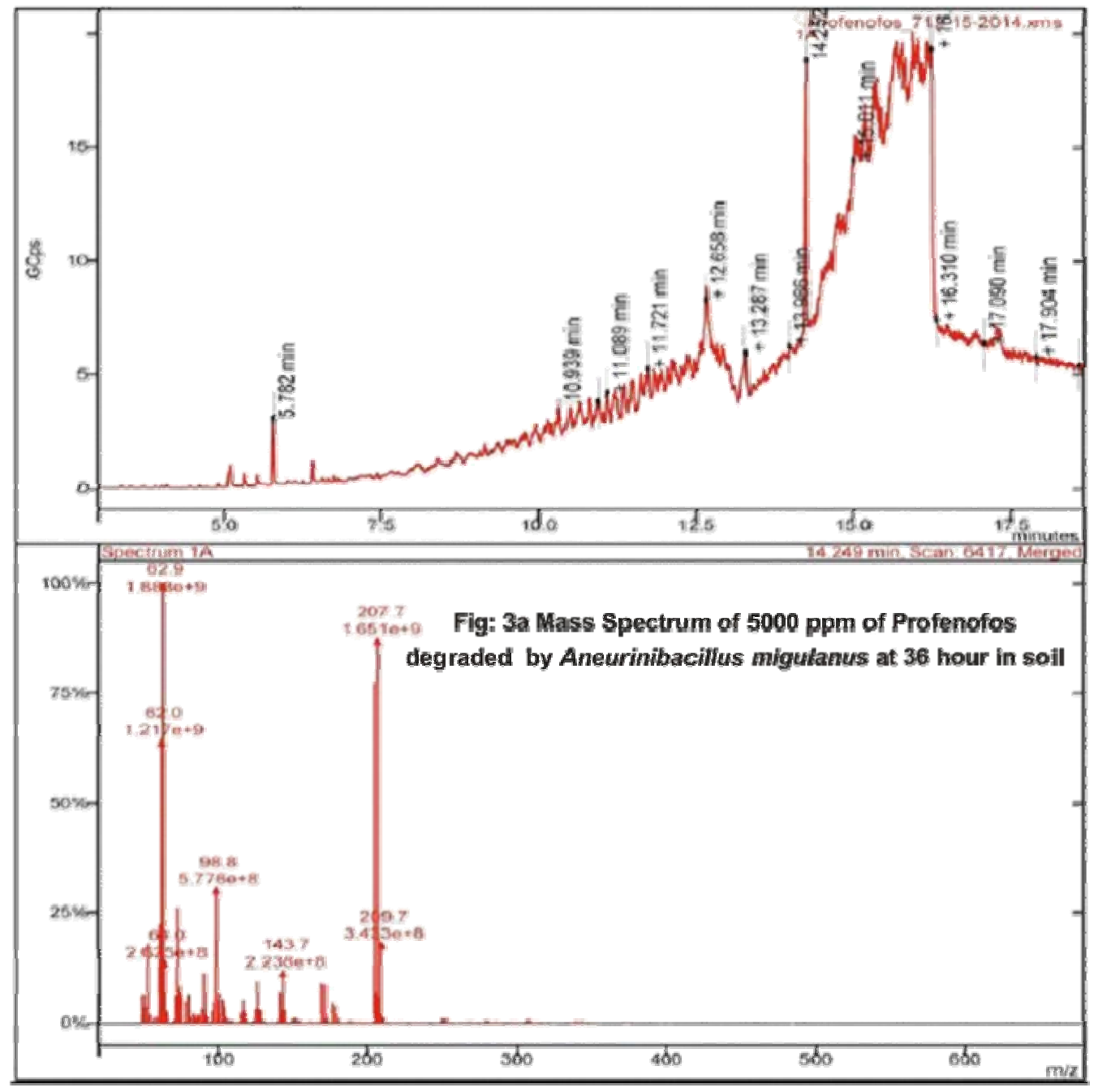


Table 2: Biodegraded metabolites of Profenofos in soil detected by G C-MS

\begin{tabular}{|c|c|c|}
\hline Treatment & R.T & Residues obtained \\
\hline \multirow[t]{6}{*}{ Control (soil + 5000 ppm Profenofos) } & 4.889 & n-Propylbenzene \\
\hline & 5.087 & 1-ethyl-2-methyl benzene \\
\hline & 5.770 & Isopropyl benzene \\
\hline & 6.405 & 1,2,3-trimethyl benzene \\
\hline & 11.749 & O-Butyl 0, 0- diethyl phosphorothioate \\
\hline & 14.218 & 4-B romo-2-chloro-phenol \\
\hline \multirow{2}{*}{$\begin{array}{l}\text { Test (Soil + } 5000 \text { ppm } \\
\text { Profenofos + Bacillus cereus) }\end{array}$} & 5.782 & 1-ethyl-2-methyl- benzene \\
\hline & 14.249 & 4-B romo-2-chloro-phenol \\
\hline \multirow{10}{*}{$\begin{array}{l}\text { Test (Soil + } 5000 \text { p } \\
\text { Profenofos + } \\
\text { Aneurinibacillus } \\
\text { migulanus) }\end{array}$} & 3.893 & Ethyl benzene \\
\hline & 4.895 & n-Propyl benzene \\
\hline & 5.098 & 1-ethyl-3-methyl benzene \\
\hline & 5.332 & Isopropyl benzene \\
\hline & 6.010 & 1,2,3-Trimethyl benzene \\
\hline & 6.418 & Isopropyl benzene \\
\hline & 6.731 & 2-ethyl, 1, 3-dimethyl benzene \\
\hline & 7.450 & 2-ethyl, 1, 3-dimethyl benzene \\
\hline & 11.734 & 0-Butyl 0,0-diethyl phosphorothioate \\
\hline & 14.256 & 4-B romo-2-chloro-phenol \\
\hline
\end{tabular}

\section{Discussion}

Malghani et al., [2] have demonstrated that the degradation of profenofos by Pseudomonas putida and Burkholderia gladioli enhanced on prolonged exposure (5 days: $70 \% ; 25$ days: 96.06 and $99.37 \%$ respectively). Furthermore, they have stated that the rate of degradation of profenofos varied among different species of bacteria. According to our present study $98.01 \%$ and $99.45 \%$ profenofos degradation was achieved within 3 days using Bacillus cereus and Aneurinibacillus migulanus, respectively. 
As evinced in this study, Hina Jabeen et al., [3] have demonstrated that $93.39 \%$ of profenofos was degraded and revealed that 4- bromo - 2-chlorophenol was the major metabolite which was subsequently metabolized to simpler compounds. Sumana Siripattanakul-Ratpukdi et al., [4] opined that integration of bioaugmentation and biostimulation techniques could trigger the bioremediation of profenofos effectively.

The acceleration of profenofos degradation by Aneurinibacillus migulanus observed in this study is in good accord with our previous findings that compared to Bacillus cereus, Aneurinibacillus migulanus enhanced the degradation of Lambda cyhalothrin [5].Furthermore, the resultant metabolite of profenofos degradation by bacteria in soil observed in this study lies in parallel to the bacterial mediated degradative metabolites of profenofos assayed in M SM in our previous study [6].

\section{Conflict of Interest}

The authors declare no conflict of interest

\section{References:}

1. Sneath, P.H.A., M air, S.N., Elisabeth, M., and Sharpe and, G. Holt., 1994, "Bergeys manual of systematic bacteriology" Williams and Wailkins, Baltimore. USA.

2. Malghani, S., Chatterjee, N., Yu, H.S., and Luo, Z., 2009, "Isolation and identification of profenofos degrading bacteria" Brazilian J ournal of M icrobiology 40, pp. 893-900.

3. Jabeen, H., Iqbal, S., Anwar, S., and Parales, R.E., 2015, "Optimization of profenfos degradation by a novel bacterial consortium PBAC using response surface methodology" International Biodeterioration and Biodegradation 100, pp. 89-97.

4. Siripattanakul -Ratpukdi, S., Vangnai, A.S., and Patichot, W., 2017, "Enhancement of Profenofos Remediation using stimulated bioaugmentation technique" Journal of Advanced oxidation technologies 20 (2).

5. A nitha, P., and U mamaheswari, S., 2017, "Profenofos degradation potential of Bacillus cereus and A neurinibacillus migulanus isolated from paddy crop field soil" Journal of Pure and Applied microbiology 11(1) pp.221-227.

6. A nitha, P., U mamaheswari, S., 2016, "Prevalence of pesticide degrading bacteria in paddy crop field" Der Pharmacia Letter, 8(1), pp. 281-295. 